\title{
A comparative study of carbon stocks in the Sal forest (Shorea robusta) in core and buffer zones of Shuklaphanta National Park, Nepal
}

\author{
Sushila Bhatta ${ }^{1}$, Animesh Poudel ${ }^{1}$ and Yam Bahadur $\mathrm{KC}^{1^{*}}$ \\ 1 Tribhuvan University, Institute of Forestry, Hetauda Campus, Nepal
}

\section{KEYWORDS}

\section{Biomass}

Carbon stock

Buffer zone

Core area

Shorea robusta

Soil organic carbon

\begin{abstract}
Forests play a significant role in sequestering carbon and regulating the global carbon and energy cycles. The amount of carbon in different carbon pools also varies at regional to local scales depending upon the environmental factors and forest management practices. This study was carried out to quantify and compare the carbon stocks in the Sal ( $S$. robusta) forest in the core and buffer zones of Shuklaphanta National Park in Kanchanpur district of Nepal. A total of 50 sample plots with 25 in each core and buffer zone were laid in the field. The total carbon stock in the core zone was estimated to be $258.56 \mathrm{t} / \mathrm{h}$ a with $75.64 \%$ in biomass and $24.36 \%$ in the soil. In the buffer zone, the total carbon stock was almost $25 \%$ lower than that at the core zone but a slightly higher composition of biomass (i.e, $80.41 \%$ of $193.3 \mathrm{t} / \mathrm{ha}$ ). These differences are likely due to the effect of the differences in management practice in the core and buffer zones. These estimates suggest that national parks have the great potential to sequester more carbon than the buffer zones. Findings from this study provide useful information on how different management practices could alter forest carbon stocks in Nepal.
\end{abstract}

\section{Introduction}

Carbon sequestration is the capture and secure storage of carbon that would otherwise be emitted to or remain in the atmosphere (FAO 2000). Forests play an important role in the local, regional, and global carbon cycle by storing large quantities of carbon in vegetation and soil and exchanging carbon with the atmosphere through photosynthesis and respiration (Brown and Pearce 1994). Forest vegetation and soil share almost $60 \%$ of the world's terrestrial carbon (Winjum et al. 1992). The sink of carbon sequestration in forests and wood products helps offset the release of carbon dioxide to the atmosphere from humaninduced processes, such as urbanization, deforestation, forest degradation, forest fires, and fossil fuel consumption. Carbon emissions from deforestation account for an estimated

* Corresponding author

E-mail address: kcyam40@gmail.com

Received 15 July 2021 Accepted 9 November 2021 
$20 \%$ of global carbon emissions (IPCC 2006), which is second only to emissions from fossil fuel combustion (Campbell et al. 2008). To successfully reduce greenhouse gas emissions from land cover change, effective strategies for protecting natural habitats are needed.

The establishment of protected areas (PAs) is one of the most effective strategies for the reduction of deforestation and biodiversity loss (Coetzee et al. 2014; Collins and Mitchard 2017; Pradhan et al. 2019). PAs are also a climate change mitigation strategy that can help reduce the atmospheric load of carbon dioxide (Ricketts et al. 2010). PAs play a significant role in mitigating the impacts of climate change on biodiversity and providing safer habitats for species to provide opportunities for the management of plants that can yield positive effects (Lehikoinen et al. 2018). Among these opportunities is the sustainable management of stand structure to increase biomasses and sequester more carbon. The extent to which PAs are effective at conserving their carbon stores is not well explored. This depends on many factors, such as whether areas are actively managed or not, the level of enforcement, the level of resource use permitted, land-use change pressures, and governance. The majority of the study focused on forest protected areas suggests that protected areas are an effective tool for reducing deforestation within their boundaries (Clark et al. 2008). Estimation of total biomass and soil carbon sequestered in any forest is very important as it gives ecological and economic benefits to the local people. So, above-ground biomass and below-ground root biomass both need to be measured to enable better calculations of forest carbon (Hamburg 2000). Reducing Emissions from Deforestation and Degradation (REDD+) which includes the roles of conservation, sustainable management of forest, and enhancement of carbon stocks, is an initiative to protect the existing forest and enhance forest cover. Under the REDD+ framework, developing countries are encouraged to enhance their forest cover in return for carbon credits to prevent people from cutting trees and instead earn their livelihood from preserving the forests. REDD+ mechanism has a brighter prospect for a country like Nepal, where $23.39 \%$ area of Nepal is covered by protected areas and is designated with the objectives of not only conserving biodiversity but also fulfilling an important role of maintaining the terrestrial carbon stocks. It is also useful to make good mitigation strategy for climate change effects, as Nepal is a member of the Forest Carbon Partnership Facility (FCPF), an innovative approach for financing efforts to combat climate change.

Sal (S. robusta) is the most dominant species of the tropical and subtropical broadleaved forest of Nepal (Jackson 1994). It has the highest stem volume $\left(31.76 \mathrm{~m}^{3} /\right.$ ha or $\left.19.28 \%\right)$ in forest at the national level (DFRS 2015). Sal forests not only have higher economic value but also serve as an important ecological benefit in the form of slackening global warming and climate change through sequestering atmospheric carbon dioxide (Shrestha 2008). The quantification of sequestered carbon in both forests profiles with different management regimes could be important for better management of natural resources in Nepal.

Species composition, stand age, and management practices as well as site characteristics such as soil properties and climate can influence local carbon stocks and fluxes (Mund and Schulze 2006). The amount of carbon in different pools such as deadwood, soil, and aboveground biomass may also depend on environmental factors and management practices. Numerous studies have been carried out in Nepal to assess the carbon stock in different land-use types, forest management regimes and species ( e.g. Shrestha et al. 2019; Aryal et al. 2017; KC et al. 2018; Kafle et al. 2019). However, there is an information gap on the differential amount of carbon stocking in protected areas and community-managed forests in the current scenario of the Terai forest in Nepal. Knowledge of carbon stocks is important in developing the strategies for the 
different management operations. Therefore, the present study aims to quantify and compare the above and below-ground biomass carbon stocks and soil organic carbon stocks within the Sal forest in the core and the buffer zones of Shuklaphanta National Park, along with the similar climate and altitudinal range, located at Terai region of Kanchanpur District, Nepal.

\section{Materials and Methods}

\section{Study area}

The present study was undertaken in the core area and buffer zone community forest (BZCF), Baijnath of Shuklaphanta National Park with similar climate and altitudinal ranges, located at the far south-western Terai of Kanchanpur district in Nepal (Figure 1). The climate of the region is tropical with an altitude ranging from $174 \mathrm{~m}$ to $1386 \mathrm{~m}$ from the mean sea level. The average temperature ranges from $7^{\circ} \mathrm{C}$ in

Sukhlaphanta National Park in Nepal's Map
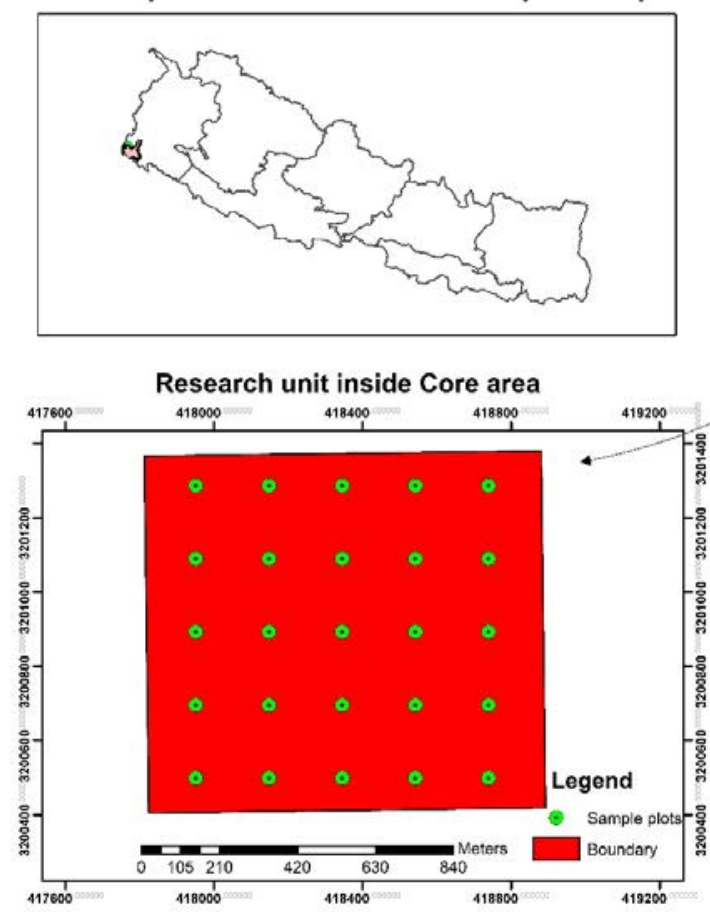

Figure 1: Location of the study area winter to $42^{\circ} \mathrm{C}$ in autumn with an average annual precipitation of $1579 \mathrm{~mm}$. The total area of Shuklaphanta National Park is $305 \mathrm{~km}^{2}$, with a buffer zone of $243 \mathrm{~km}^{2}$. The vegetation types primarily include Sal (S. robusta) forest, Sal savanna, which is part of the continuum between climax forest and grassland that is maintained by fire and floods (DNWC 2021). Sal forest is the most dominant vegetation type in the study area. The core zone is managed by DNPWC, whereas the buffer zone community forest is managed by the local community. The buffer zone community forest is located in Bedkot Municipality, which covers an area of 605 ha. This buffer zone community forest has sufficient growing stock to fulfilll the basic forest needs of local people. The forest management practices, such as thinning, pruning, clearance of leaf litter, cutting and logging of trees, and others have been followed as per their operational plan approved by the Warden of the National Park.

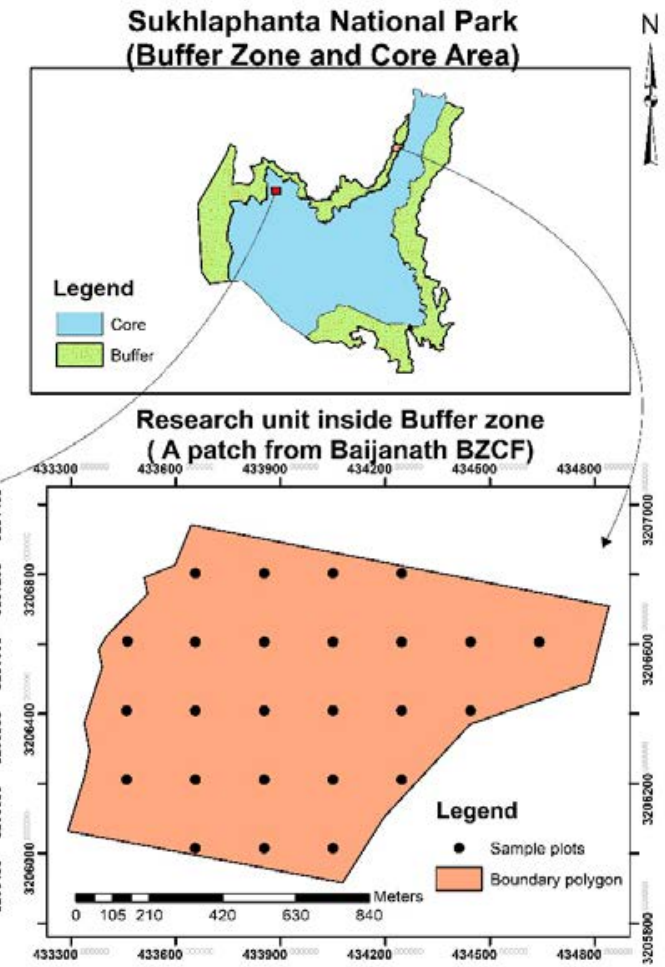




\section{Data collection}

This study employed a systematic random sampling method to collect data with a sampling intensity of $1.25 \%$ (MFSC 2004). From each forest zone (i.e., PA and buffer area), a 100 ha forested area was selected randomly and was divided into 25 plots. Circular nested plots of different radius were laid covering $500 \mathrm{~m}^{2}, 100 \mathrm{~m}^{2}$, and $25 \mathrm{~m}^{2}$ within a plot to measure trees, poles, and saplings, respectively. Diameter at breast height (DBH) was measured using diameter tape and the height of each tree was measured using a Sunto-clinometer. The soil samples at depths $0-10 \mathrm{~cm}, 10-20 \mathrm{~cm}$, and $20-30 \mathrm{~cm}$ were collected from ten sample plots each plot in four cardinal directions using soil corer and placed in the labeled plastic bag. The collected samples were brought to the laboratory to determine the soil organic carbon.

\section{Data analysis}

\section{(i) Tree and Pole aboveground biomass}

The Above-ground tree biomass (AGTB) was calculated using equation (I) for tropical moist hardwood forests suggested by Chave et al. (2005). $\mathrm{AGTB}=0.0509{ }^{*} \rho \mathrm{D} 2 \mathrm{H}$

where, AGTB is the aboveground tree biomass $(\mathrm{kg}) ; \rho$ is the wood-specific gravity $(\mathrm{gm} / \mathrm{cm} 3)$; $\mathrm{D}$ is Diameter at Breast Height $(\mathrm{DBH})(\mathrm{cm})$, and $\mathrm{H}$ is the tree height $(\mathrm{m})$.

\section{(ii) Sapling aboveground biomass}

The above-ground sampling biomass (AGSB) was calculated by using the formula (II) suggested by Tamrakar (2000).

$\log (A G S B)=a+b \log (D)$

where, AGSB is the aboveground sampling biomass (kg); Log is natural log; 'a' and 'b' are regression coefficients; $\mathrm{D}$ is the diameter at breast height $(\mathrm{cm})$.

\section{(iii) Belowground biomass}

Below ground biomass was calculated using the root to shoot ratio method in which root to shoot value was taken as 1:5 (i.e. the belowground biomass is $20 \%$ of the above-ground biomass) following MacDicken (1997).

\section{(iv) Carbon stock}

All the biomasses were converted to carbon stock using the IPCC (2006) default fraction of $0.47 . \mathrm{C}=0.47 \times$ total dry biomass (III)

\section{(v) Soil Organic Carbon}

Total carbon stock in forest soil was calculated using equation (IV) following Pearson et al. (2005).

$\mathrm{SOC}=\rho^{\star} \mathrm{d}^{*} \% \mathrm{C} \quad(\mathrm{IV})$ where, SOC is the soil organic carbon stock per unit area ( $\mathrm{t} / \mathrm{ha}), \mathrm{p}$ is the soil bulk density ( $\mathrm{g} /$ $\mathrm{cm} 3$ ), $\mathrm{d}$ is the total depth at which the sample was taken $(\mathrm{cm})$, and \% C is carbon concentration (\%). Soil organic carbon was analyzed using Walkey and Black (1934)in the Soil Testing Laboratory of Sundarpur, Kanchanpur District, Nepal.

\section{(vi) Total carbon stock}

The total carbon stock (TCS) density was calculated using equation (V) by summing up $\mathrm{C}$ stock in the TAGC, TBGC, and SOC.

$\mathrm{TC}=\mathrm{TAGC}+\mathrm{TBGC}+\mathrm{SOC}(\mathrm{V})$ where, TC is Total Carbon Stock ( $\mathrm{t} / \mathrm{ha})$; TAGC is Total above ground Carbon Stock ( $\mathrm{t} / \mathrm{ha}$ ); TBGC is Total below ground Carbon Stock ( $t / h a)$. The total carbon stock was converted to tons of carbon dioxide equivalent by multiplying it by 3.67 (Pearson et al. 2005).

Table 1: Distribution of above ground and below ground carbon stock

\begin{tabular}{|c|c|c|c|c|c|c|c|}
\hline \multirow[t]{2}{*}{ Sites } & \multicolumn{3}{|c|}{$\begin{array}{l}\text { Above Ground Carbon Stock } \\
(\mathrm{t} / \mathrm{ha})\end{array}$} & \multicolumn{3}{|c|}{$\begin{array}{l}\text { Below Ground Carbon Stock } \\
(\mathrm{t} / \mathrm{ha})\end{array}$} & \multirow[t]{2}{*}{$\begin{array}{l}\text { Total Carbon } \\
\text { Stock (t/ha) }\end{array}$} \\
\hline & Trees & Poles & Saplings & Trees & Poles & Saplings & \\
\hline Core area & 128.43 & 30.18 & 4.36 & 25.68 & 6.03 & 0.87 & 195.58 \\
\hline Buffer Zone & 64.62 & 62.85 & 2.05 & 12.93 & 12.57 & 0.41 & 155.44 \\
\hline
\end{tabular}


Data were analyzed using descriptive and inferential statistical tools in $\mathrm{R}$ software. The graphs and tables were constructed using MSExcel 2010. To compare the carbon stock densities between the two areas, t-test was used at a 5\% level of significance with $\mathrm{R}$ statistical software.

\section{Results and Discussion}

\section{Carbon Stocks}

The above-ground carbon stock was found to be $162.98 \mathrm{t} /$ ha in the core area with $128.43 \mathrm{t} /$ ha, $30.18 \mathrm{t} / \mathrm{ha}$, and $4.36 \mathrm{t} / \mathrm{ha}$, in trees, poles, and saplings respectively (Table 1 ). This amount was higher than the above-ground carbon stock in the buffer zone community forest, where the estimated carbon stock was found to be 129.53 t/ha $(64.62 \mathrm{t} / \mathrm{ha}, 62.86 \mathrm{t} / \mathrm{ha}$, and $2.05 \mathrm{t} / \mathrm{ha}$ in the trees, poles, and saplings, respectively). Similarly, the below-ground carbon stock was found to be higher in the core zone forests (32.59 $\mathrm{t} / \mathrm{ha}$ vs $25.91 \mathrm{t} / \mathrm{ha}$ in the buffer zone forests) though the below-ground carbon stock in the poles of buffer zone forests was found to be slightly higher than that of core zone forests (Table 1). The core zone showed a total carbon stock of $195.58 \mathrm{t} / \mathrm{ha}$, which was $25.82 \%$ higher than in the buffer zone (155.44 t/ha) (Table 1). Carbon stocks of trees, poles, and saplings were significantly different for both sites $(\mathrm{p}<0.05$; Table 2).

\section{Soil Organic Carbon (SOC)}

The soil organic carbon in the core area $(62.98$ $\mathrm{t} / \mathrm{ha}$ ) was significantly $(\mathrm{p}<0.05$; Table 2$)$ higher than in the buffer zone (37.88 t/ha) of the National Park. The average soil organic carbon in the core area was found to be highest in the uppermost layer $(0-10 \mathrm{~cm})$ with $33.42 \mathrm{t} /$ ha and lowest in the lowermost layer (20-30 $\mathrm{cm}$ ) with $13.22 \mathrm{t} /$ ha (Figure 2). Likewise, the average soil organic in buffer zone community forest was found to be highest in the uppermost layer $(0-10 \mathrm{~cm})$ with $17.57 \mathrm{t} / \mathrm{ha}$ and lowest in the lowermost layer with $9.52 \mathrm{t} / \mathrm{ha}(20-30 \mathrm{~cm})$ (Figure 3). These findings and carbon stock values from this study correspond with Khadka et al. (2019), who found that the soil organic carbon inside Banke National park (68.42 t/ha) was higher than outside Banke National park $(59.59 \mathrm{t} / \mathrm{ha})$. SOC was higher at the upper layers that gradually decreased with the soil depth. A higher amount of soil organic carbon may be also due to the higher density of trees, poles, and saplings and their organic residues. The presence of higher organic carbon in the top layer may be due to the decomposition of forest leaf litter and deadwood in the uppermost layer under suitable environmental conditions.

\section{Total carbon stock}

Above ground and below-ground biomass carbon stocks when pooled together registered carbon stock (195.58 t/ha) in the core zone, and carbon stock (155.44 t/ha) in the buffer zone. The soil organic carbon registered carbon stock $(62.98 \mathrm{t} / \mathrm{ha})$ in the core area, and carbon stock $(37.88 \mathrm{t} / \mathrm{ha})$ in the buffer zone respectively. In both zones, the contribution of aboveground biomass carbon was maximum to the total carbon stock, followed by soil organic

Table 2: Biomass carbon stock, SOC, total carbon stock ( $t / h a)$, and result of the $t$-test.

\begin{tabular}{lcccccc}
\hline \multicolumn{1}{c}{ Carbon pool } & df & Core Area & Buffer Zone & Mean & P-value & Remarks \\
\hline Tree carbon stock $(\mathrm{t} / \mathrm{ha})$ & 46 & 154.12 & 77.55 & 115.83 & 0.0056 & $*$ \\
Pole carbon stock $(\mathrm{t} / \mathrm{ha})$ & 46 & 36.22 & 75.43 & 55.82 & 0.0051 & $*$ \\
Sapling carbon stock $(\mathrm{t} / \mathrm{ha})$ & 39 & 5.24 & 2.47 & 3.85 & 0.0015 & $*$ \\
Total of biomass carbon stock & & 195.58 & 155.44 & 175.51 & & \\
Soil organic carbon $(\mathrm{t} / \mathrm{ha})$ & 18 & 62.98 & 37.88 & 50.43 & 0.0009 & $*$ \\
Total carbon stock & & 258.56 & 193.33 & 225.94 & & \\
Remarks: ${ }^{*}=$ significant at $\mathrm{P}<0.05$ & & & & & & \\
\hline
\end{tabular}




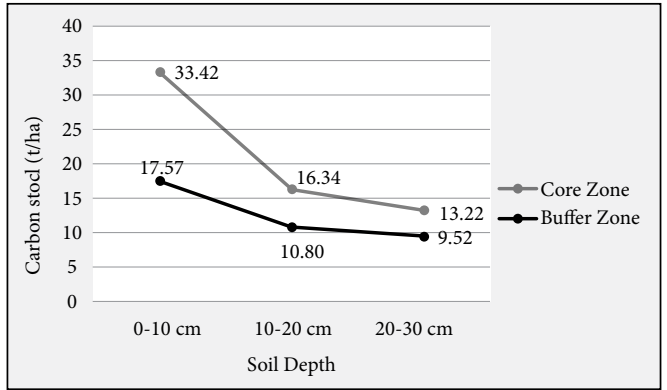

Figure 2: Soil organic carbon in different soil depths

carbon and below-ground biomass. The core area forest stored total carbon stock (258.56 $\mathrm{t} / \mathrm{ha}$ ) was considerably higher than those in the buffer zone (193.32 t/ha) (Figure 3). This difference is expected to be from the effect of management practices and land-use patterns, as the environmental conditions across both sites are similar. The thinning, pruning, clearance of leaf litter, cutting and logging of the tress for livelihood sustainability of local people and the disturbance from cattle grazing, mining activities in the river beds inside the forest, might have led to lower carbon stock in the buffer zone.

In a study by DFRS, soil organic carbon and tree component carbon stock in the forest of the Terai region in 2015 were found to be 33.66 t/ha, and 104.47 t/ha, respectively (DFRS 2015), which are lower than those found in this study. This is expected, given that the tree samples are more mature than the ones surveyed by DFRS. The study done by Pandey et al. (2016) showed that the estimated biomass carbon stock and

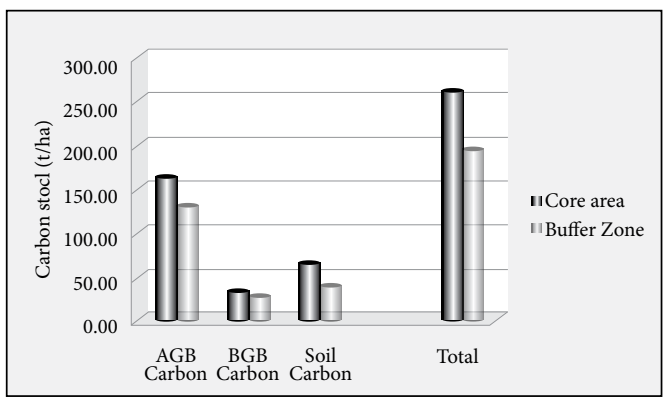

Figure 3: Carbon stock in the core area and buffer zone soil organic carbon stock were $384.20 \mathrm{t} / \mathrm{ha}$, and $95.09 \mathrm{t} / \mathrm{h}$ respectively in Terai $S$. robustadominated community forest, which is higher than the present study. Similarly, the study done by Mbaabu et al. (2014) found that the value of the average carbon stock in the community forest of Chitwan in the Terai was found to be $244 \mathrm{t} / \mathrm{ha}$, which is slightly higher than the present study. The main reason for the highest carbon stock of S. robusta was the dominancy of this species in the community forests than that of the current study area. The study conducted by Gurung et al. (2015) showed the carbon stocks in the protected areas and community forests were 291.55 t/ha, and 237.15 t/ha, respectively, in the Terai Arc Landscape, Nepal. These results are comparable and slightly higher than the present estimates of carbon stock values of $258.56 \mathrm{t} / \mathrm{ha}$ in the core zone and $193.33 \mathrm{t} / \mathrm{ha}$ in the buffer zone. Khadka et al. (2019) reported that carbon stock in Banke National Park and outside Banke National Park was found to be $218.92 \mathrm{t} / \mathrm{ha}$ and $195.86 \mathrm{t} / \mathrm{ha}$, which is nearly similar to the present finding. Soil organic carbon stock was consistently lower at all soil depths after disturbance compared to undisturbed conditions. The carbon stock values are closer and variation in carbon stock values may be due to other factors such as stand density. The carbon stock values would vary according to the geographical location, plant species, age of the stand, aboveground input received from leaf litter, decomposition of fine roots below ground, management practices, and other operating ecological factors (Singh et al. 1987).

\section{Conclusion and Recommendations}

This study was carried out to assess and compare the carbon stock of the core and surrounding areas (buffer zone) of Sal forests in the Shuklaphanta national park. Results suggest that Sal forests in the core zone store more carbon per unit area than those in the buffer zone within similar climate and altitudinal ranges, largely due to minimal human interventions in the core zone. For 
example, current restrictions in the harvesting of forest products allow forests to be in their natural conditions in the core area, while open forests in the buffer zone are heavily intervened with several forest management activities that include the extraction of forest products. The soil organic carbon appears to decline with depth across forests in both zones and was also found to be higher in core zone forests as indicated by its relatively high below-ground carbon stocks. Results suggest that protected areas play a significant role in the sequestration of atmospheric carbon and reducing greenhouse gas emissions by storing more carbon in different vegetation and soil than managed forests. However, it is required to assess the trend of carbon sequestration in PAs to confirm the effectiveness of PAs in REDD+ like financial incentives. Future studies should explore the spatiotemporal distribution of carbon stock across the core PAs and its surrounding buffer zone area in Nepal. In addition, how different management practices alter carbon stocks in Sal forests should be explored to help identify the best management practice that can minimize $\mathrm{CO} 2$ emissions, as all forests cannot be managed as PAs. Overall, this study provides useful background for future research to assess the trend of carbon sequestration in PAs (core areas) to bring PAs to the carbon incentives including REDD+ and also to understand how different management practices alter carbon stock across different forest systems in Nepal. 


\section{References}

Aryal, B.; Pandey, M.; Giri, A.; Bhattarai, B. P. (2017). Carbon sequestration and $\mathrm{CO} 2$ mitigation in a burned ecosystem of Pinus roxburghii forest in Langtang National Park, Nepal. Tropical Plant Research. https://doi. org/10.22271/tpr.2017.v4.i2.039

Brown, K., Pearce, D. (1994). The economic value of non-timber benefits of tropical forests: carbon storage. In The Economics of Project Appraisal and the Environment; New Horizons in Environment Economics (pp. 102-123). Aldershot Publishing, Chelttenham, UK.

Campbell, A., Miles, I., Lysenko, I., Hughes, A., Gibbs, H. (2008). Carbon storage in protected areas: Technical report. In United Nations Environment Program-World Conservation Monitoring Centre. https://www.unep-wcmc. org/resources-and-data/carbon-storage-inprotected-areas

Chave, J.; Andalo, C.; Brown, S.; Cairns, M.A.; Chambers, J.Q.; Eamus, D.; Kira, T. (2005). Tree allometry and improved estimation of carbon stocks and balance in tropical forests. Oecologia, 145(1). https://doi.org/10.1007/ s00442-005-0100-x

Clark, S., Bolt, K., Campbell, A. (2008). Protected areas: an effective tool to reduce emissions from deforestation and forest degradation in developing countries. World Conservation Monitoring Centre, UNEP, Cambridge, U.K.

Coetzee, B., Gaston, K., Chown, S. (2014). Local scale comparisons of biodiversity as a test for global protected area ecological performance: ameta-analysis. PLoS One. 9:E105824.

Collins, M.; Mitchard, E. (2017). A small subset of protected areas are a highly significant source of carbon emissions. Sci Rep. www. ncbi.nlm.\%0Anih.gov/pmc/articles/ PMC5301250/

DFRS. (2015). State of Nepal's Forest Issue December). Department of Forest Research and Survey. https://doi.org/978-9937-8896-3-6

DNWC. (2021). Department of National Parks and Wildlife Conservation. https://nnwc.gov.np/ en/

FAO. (2000). Carbon sequestration options under the Clean Development Mechanism to address land degradation. Food and Agriculture Organization of the United Nations.

Gurung, M.B.; Bigsby, H.; Ross, C.; Manandhar, U. (2015). Estimation of carbon stock under different management regimes of tropical forest in the Terai Arc Landscape, Nepal. Forest Ecology and Management, 356. https:// doi.org/10.1016/j.foreco.2015.07.024

Hamburg, S. (2000). Simple rules for measuring changes in ecosystem carbon in forestryoffset projects. Mitigation and Adaptation Strategies for Global Change. Mitigation and Adaptation Strategies for Global Change, 5(1), 25-37.

IPCC. (2006). Guidelines for National Greenhouse Gas Inventories. Intergovernmental Panel on Climate Change.

Jackson, J. K. (1994). Afforestation, Manual of Forest, in Nepal (Volume I). 2nd edition. Research and Survey Center, Kathmandu, Nepal.

Kafle, G.; Timilsina, Y.P.; Sharma, R.P.; Bartaula, B. (2019). Contribution of dead wood and forest soil to carbon sequestration in Parsa National Park, Nepal. Journal of Agriculture and Forestry University, 3, 113-123.

KC, A., Manandhar, R., Paudel, R., Ghimire, S. (2018). Increase of forest carbon biomass due to community forestry management in Nepal. Journal of Forestry Research, 29(2), 429-438. https://doi.org/10.1007/s11676017-0438-z

Khadka, G.B.; Mandal, R.; Mathema, A. (2019). Comparison Growing Stock, Carbon Stock and Biodiversity in and Around Banke National Park, Nepal. International Journal of Botany, 5(3), 21-26.

Lehikoinen, P.; Santangeli, A.; Jaatinen, K.; Lehikoinen, A. (2018). Protected areas act as a buffer against detrimental effects of climate change-Evidence from large-scale, longterm abundance data. Global Change Biology. https://doi.org/10.1111/gcb.14461

MacDicken, K. (1997). A Guide to Monitoring carbon Storage in Forestry and Agroforestry Projects. Winrock International Institute for Agricultural Development.

Mbaabu, P.R.; Hussin, Y.A.; Michael, W.; Hammad, G. (2014). Quantification of carbon stock to understand two different forestmanagement regimes in Kayar Khola watershed, Chitwan, Nepal. Indian Society of Remote Sensing, 42(4). https://doi.org/10.1007/s12524-0140379-3

MFSC. (2004). Community Forest Inventory Guideline. Ministry of Forest and Soil Conservation, Nepal.

Mund, M.,Schulze, E. (2006). Impacts of forest management on the carbon budget of European Beech (Fagus sylvatica) forests. 
Allgemeine Forst Und Jagdzeitung, 177(3), 47-63. https://doi.org/10.20431/24554316.0504001

Pandey, H.P.; Bhusal, M. (2016). A comparative study on carbon stock in Sal (Shorea robusta) forest in two different ecological regions of Nepal. Banko Janakari 26(1), 26(1), 24-31.

Pearson, T. R., Brown, S., Ravindranath, N. H. (2005). Integrating Carbon Benefit Estimates into GEF projects: Capacity Development and Adaptation Group Guidelines. Global Environment Facility, United Nations Development Program.

Pradhan, A., Ormsby, Alison A., Niranjan, B. (2019). A comparative assessment of tree diversity, biomass and biomass carbon stock between a protected area and a sacred forest of Western Odisha, India. Écoscience. https://doi.org/10 $.1080 / 11956860.2019 .1586118$

Ricketts, T.H.; Soares, F.B.; Da Fonseca, G.; Pfaff, A.; Nepstad, D.; Petsonk, A.; Anderson, D.; Boucher, D.; Cattaneo, A.; Conte, M. (2010). Indigenous lands, protected areas, and slowing climate change. PLoS Biol. 8:E1000331.

Shrestha, L.J.; Devkota, M.P.; Sharma, B. K. (2019). Are
Sacred Groves of Kathmandu Valley Efficient in Sequestring Carbon? Journal of Botany, 7 , 1-6. https://doi.org/10.1155/2019/9478932

Shrestha, B. P. (2008). An Analytical Study of Carbon Sequestration in Three DifferentForest Types of Mid-Hills of Nepal. M.Sc Thesis. Tribhuvan University, Institute of Forestry, Pokhara.

Singh, A. K., Kumar, V. K., \& Singh, J. (1987). Forest Resource Economy and Environment Concept. Publishing Company, New Delhi, India.

Tamrakar, P. R. (2000). Biomass and volume tables with species description for community forest management. Ministry of Forests and Soil Conservation, Nepal.

Walkley, A. E., Black, J. A. (1934). An Examination of the Method for Determining Soil Organic Method, and Proposed Modification of the Chromic Acid Titration Method. In Soil Science. https://doi.org/10.1097/00010694193401000-00003

Winjum, J.K.; Dixon, R.K.; Schroeder, P. E. (1992). Estimating the global potential of forest and agroforest management practices to sequester carbon. Water, Air and Soil Pollution (Netherlands), 64(1-2), 213-277. 